WSRC-RP-9I-1051

DE92 018128

\title{
ADDITIONAL INFORMATION FOR IMPACT RESPONSE OF THE RESTART SAFETY RODS (U)
}

by

W. W. F. Yau

Westinghouse Savannah River Company

Savannah River Site

Aiken, South Carolina 29808

The information contained in this document was prepared in connection with work done under Contract No. DE-AC09-89SR 18035 with the U.S. Department of Energy. By acceptance of this report, the publisher and/or recipient acknowledges the U.S. Government's right to retain a nonexclusive, royaliy-free license in and to any copyright covering this report, along with the right to reproduce and to authorize others to reproduce all or part of the copyrighted report.

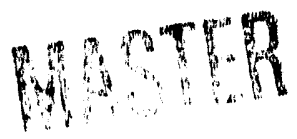




\section{DISCLAIMER}

This report was prepared as an account of work sponsored by an agency of the United States Government. Neither the United States Government nor any agency thereof, nor any of their employees, makes any warranty, express or implied, or assumes any legal liability or responsibility for the accuracy, completeness, or usefulness of any information, apparatus, product, or process disclosed, or represents that its use would not infringe privately owned rights. Reference herein to any specific commercial product, process, or service by trade name, trademark, manufacturer, or otherwise does not necessarily constitute or imply its endorsement, recommendation, or favoring by the United States Government or any agency thereof. The views and opinions of authors expressed herein do not necessarily state or reflect those of the United States Government or any agency thereof.

This report has been reproduced directy from the best available copy.

Available to DOE and DOE contractors from the Office of Scientific and Technical Information, P.O. Box 62, Oak Ridge, TN 37831; prices available from (615) 576-8401, FTS 626-8401.

Available to the public from the National Techncial Information Service, U.S. Department of Commerce, 5285 Port Royal Rd., Springfield, VA 22161. 


\section{$\cos 24+100010$ \\ WESTINGHOUSE SAVANNAH RIVER COMPANY INTER-OFFICE MEMORANDUM}

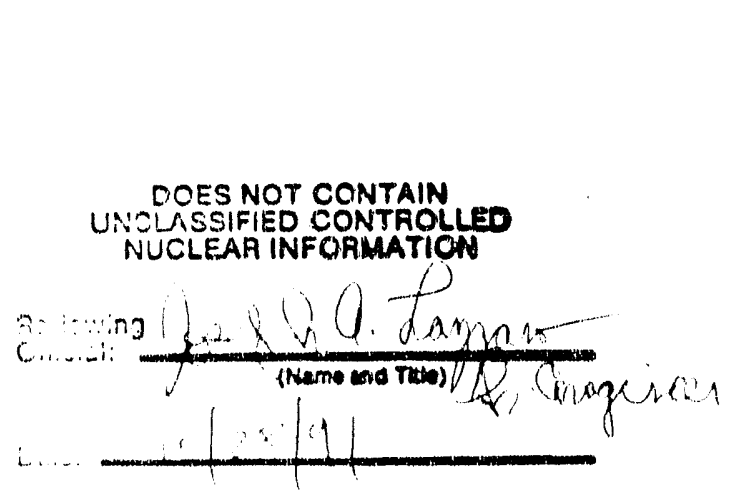

cc:

WSRC.RP.91-1051

Keywords:

FROM:

W. W. F. YAU, 773-A

$(5-1726)$

\section{ADDITIONAL INEOBMATION FOR IMPACT BESPONSE OF THE RESTART SAEETY RODS - (U) \\ Lnereduction}

WSRC-RP-91-677 studied the structural response of the safety rods under the conditions of brake failure and accidental release. It was concluded that the maximum impact loading to the safety rod is 6020 pounds based on conservative considerations that energy dissipation attributable to fluid resistance and reactor superstructure flexibility. The staffers of the Defense Nuclear Facility Safety Board reviewed the results and inquired about the extent of conservatism. By request of the RESTART team, I reassessed the impact force due to these conservative assumptions. This memorandum reports these assessments.

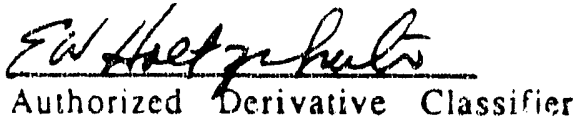


E. W. Holtzscheiter

WSRC.RP-91-1051

Page 2

October 14, 1991

\section{Summary}

When a safety rod plunges into a pool of heavy water at $60^{\circ} \mathrm{C}$, it drags a thin layer of heavy water with it. The amount of heavy water moving with the safety rod is estimated to be 1.5 pounds. Consideration of energy dissipation due to fluid viscosity reduces the impact force by 540 pounds, or $9 \%$. The reactor superstructure is more than 10,000 times heavier than a safety rod.

Consideration of inelastic collision between them shows that energy dissipation due to superstructure motion is in the order of $10^{-4}$, or negligibly small.

\section{Discussien}

A flat plate moving in a viscous fluid in the plane of the plate drags a layer of the fluid with it, and the thickness is estimated by $\delta=2(\nu \tau)^{1 / \alpha}$, where $\nu$ is the kinematic viscosity of the fluid, and $\tau$ is the duration of motion, (p. 64, Viscous Flow Theory, Vol. 1, S. I. Pai, Van Nostrand, 1956). For heavy water at $60^{\circ}, \nu=$ $0.514(10)^{-5} \mathrm{ft}^{2} / \mathrm{sec}$. The time duration is solved from the equation of motion for a safety rod plunging to a depth $y$,

$$
w-p A y=\frac{w}{g} \frac{d^{2} y}{d t^{2}}
$$

where $w=27.2$ pounds is the rod weight, $p=64 \mathrm{lb} / \mathrm{ft}^{3}$ is the weight density of heavy water, $A=0.694 \mathrm{in}^{2}$ is the rod cross-sectional area, $\mathrm{g}=32.2 \mathrm{ft} / \mathrm{sec}^{2}$ is the gravitational acceleration, and $t$ is the time variable. It $c$ an be shown that

$$
y=\frac{v_{0}}{\lambda} \sin \lambda t+\frac{1}{2} g t^{2}, \quad \lambda^{2}=\rho g A / w
$$

is a solution satisfying the initial conditions of zero depth and velocity $v_{0}=38.08$ fps (WSRC-RP-91-677). The time duration is obtained by setting $y=L=20 \mathrm{ft}$, the length of the safety rod, and solve for the time $t=t=1.114 \mathrm{sec}$. 
E. W. Holtzscheiter

WSRC-RP-91-1051

Page 3

October 14, 1991

The amount of heavy water stuck on the rod is

$$
\begin{aligned}
W^{\prime} & =2 \pi \rho D L(\nu \tau)^{1 / 2} \\
& =2 \pi(64) \frac{0.94}{12}(20)\left[0.514(10)^{-5}(1.114)\right]^{1 / 2} \\
& =1.5016
\end{aligned}
$$

where $D=0.94 \mathrm{in}$. is the rod diameter. The energy dissipated during the travel is $\mathrm{U}=0.5 \mathrm{~W}^{\prime} \mathrm{L}=15 \mathrm{ft}-\mathrm{lb}$. By reducing the amount of energy available for tube deformation by $15 \mathrm{ft}-\mathrm{lb}$, it can be shown at the maximum elongation of the housing tube is

$$
\Delta_{\max }^{\prime}=0.3811 \text { in }
$$

The impact force is proportional to the elongation, so the modified impact force considering the effect of water resistance is

$$
F^{\prime}=F \Delta_{\max }^{\prime} / \Delta_{\text {max }}=5480 \mathrm{lb}
$$

WWFY/tyb 

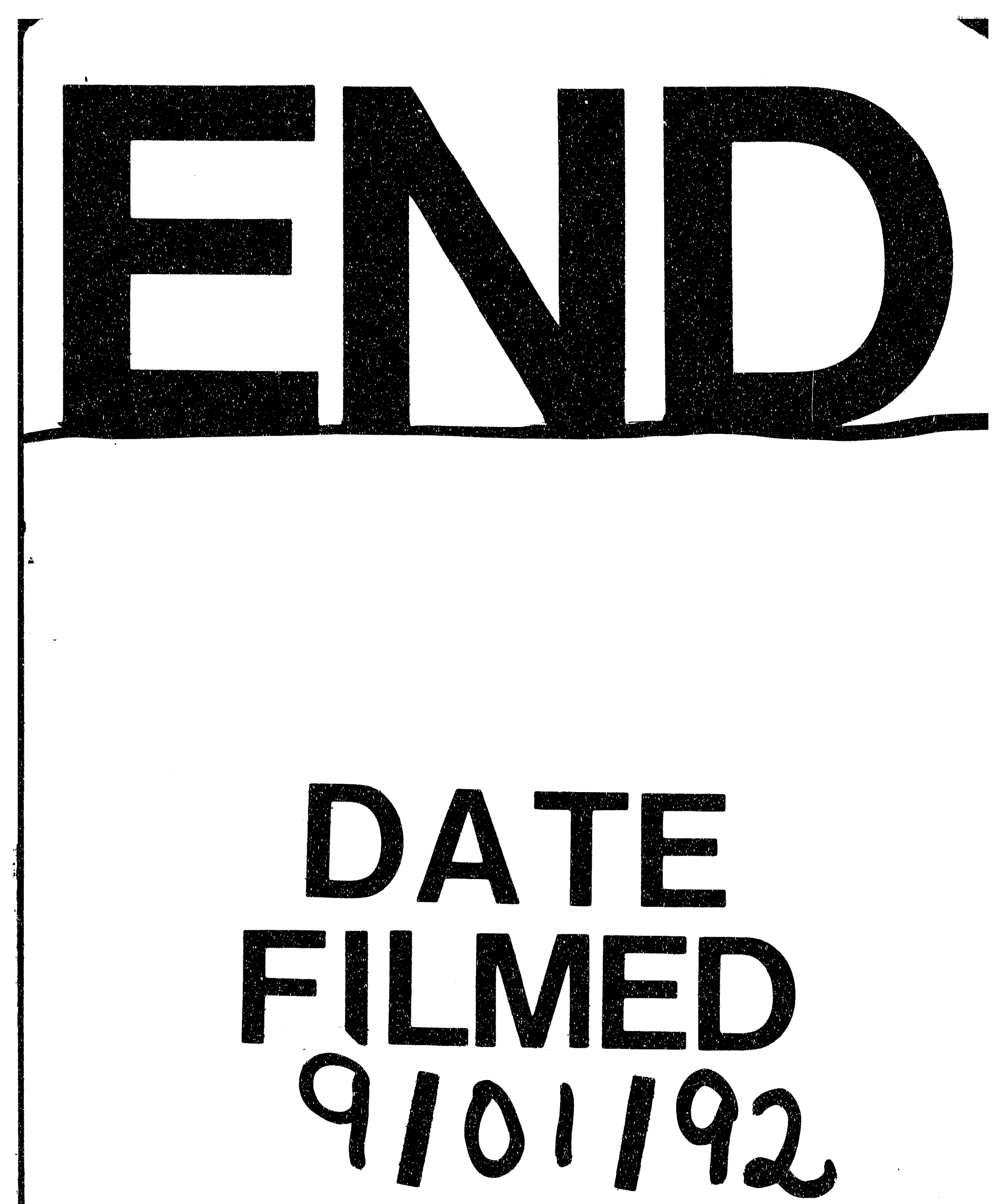
